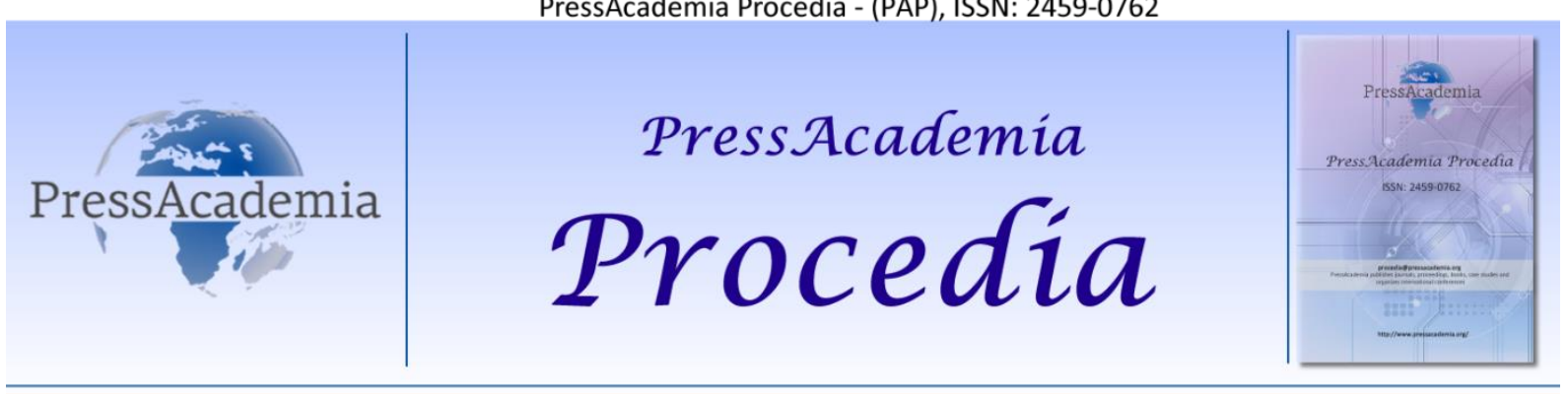

2nd World Conference on Technology, Innovation and Entrepreneurship

May 12-14, 2017, Istanbul, Turkey. Edited by Sefer Şener

\title{
EVALUATION OF CARBON FOOTPRINT FOR WOOD BASED PANEL INDUSTRY IN TURKEY
}

\author{
DOI: 10.17261/Pressacademia.2017.564 \\ PAP-WCTIE-V.5-2017(2)-p.10-18 \\ Mehtap Erdil ${ }^{1}$, Nural Yilgor ${ }^{2}$, Yigit Gungor
${ }^{3}$ Istanbul University, erdilmehtap@gmail.com
${ }^{2}$ Istanbul University, yilgorn@istanbul.edu.tr
${ }^{3}$ Gebze Technical University, yigitgungor@hotmail.com
}

\begin{abstract}
In wood-based panel industry, the importance of carbon footprint has increased due to global warming and climate change all around the world. So this topic has been studied extensively in the world, especially in developed countries. Eventhough wood based panel industry is one of the most important industry in Turkey there is not any comprehensive study in this field so this study was planned to meet the requirement in industry which release a lot of emissions to the environment. In recent years the use of wood-based panels such as fiber board, particleboard, oriented strand board, plywood etc., have been increased due to the fast growth in bulding trade in Turkey. The world's largest board producers are China, USA, Germany and Turkey respectively. This charges the industry a great responsibility for the environment because sustainable development is a development that meets the needs of the present without making a concession the ability of future generations to meet their own needs. From this perspective, it is essential to know the current status of the sector concerning $\mathrm{CO}_{2}$ footprint, energy footprint and water footprint. This study is aimed to investigate one of the largest board producer industry of Turkey whether clean production (less emission) is carried out or not. Besides, it is aimed to present some improvements to decrease the emission. Carbon footprint values are calculated as statistically with Tier method during the particle board production, and Pareto anaysis method is used for determine the footprint' problem. Consequently, a liveable environment will be provided and environmental oriented production will be supported to contribute to these properties in the industry for this issue in the scope of this research. Also, this study shall provide a general view and perception for the importance of the carbon footprint in the industrial sector.
\end{abstract}

Keywords: Carbon footprint, tier method, pareto analysis, wood based panel industry, particle board production.

\section{INTRODUCTION}

Carbon footprint originated from the terminology of ecological footprint which was proposed by Wackernagel and Rees, 1996 (Wackernagel and Rees, 1996). It is the calculation of the total value of direct or indirect $\mathrm{CO}_{2}$ emissions of the activities occur during the life cycle. According to another definition, it is a technique to identify and measure of the greenhouse gas emissions (GHG) release from each operation or activity full life cycle (Carbon Trust, 2007; IPCC, 2006; IPCC, 2007). Grubb and Ellis, 2007, defined carbon footprint as the total amount of carbon dioxide release through the combustion of fossil fuels. The major greenhouse gases emitted into the atmosphere are $\mathrm{CO}_{2}, \mathrm{CH}_{4}, \mathrm{~N}_{2} \mathrm{O}$ and some different fluorine containing halogenated compounds (Muthu, 2014). However, the most significant greenhouse gas is $\mathrm{CO}_{2}$ and it was produced from burning of fossil fuels to generate energy which is essential for the manufacture and transport of the goods. It is expressed as grams or kilograms of $\mathrm{CO}_{2}$ equivalent per kilowatt hour of generation $\left(\mathrm{g} / \mathrm{kgCO}_{2 e q} / \mathrm{kWh}\right)$ which being in charge of the different global warming effects of other greenhouse gases (Paliamentary Office of Science and Technology (POST), 2006). Hammond, 2007 suggested that ..." The property that is often referred to as a carbon footprint is actually a carbon weight of kilograms or tonnes per person or activity." Higher GHG concentrations in the earth 's atmosphere cause global warming and it causes climate change in the world. This reality forces the nations to get some precautions. The most important agreement of concerning global warming and climate change is known as Kyoto Protocol and six greenhouse gases are defined as $\mathrm{CO}, \mathrm{CO}_{2}, \mathrm{CH}_{4}, \mathrm{~N}_{2} \mathrm{O}$, perfluorocarbons, and hydrofluorocarbons which cause strongly global warming and it was thought those gases are released by human activities. (IPCC, 2007; ECCM, 2008; UN,1998). A carbon footprint measurement is a complicated and boring method. GHG produced by human activities either directly or indirectly. Direct GHG emissions are suggested as burning fossil fuels for generating electricity to heat and transport. But indirect emissions are less clear that 
emitted through life-cycles of goods and services (ECCM, 2008; Wiedmann and Minx, 2007). In this study, it is aimed to calculate $\mathrm{CO}_{2}$ emissions for each process in a particle board industry in a plant scale one of the largest producers in Marmara region, in Turkey. The plant named as X plant afterwards in this study. The amount of annual production of particle board is $423096 \mathrm{~m}^{3} /$ year in 2015. The carbon footprint is calculated according to Tier 1 method (IPCC, 2007).

\section{LITERATURE REVIEW}

\subsection{Forest Products Industry}

The forest products industry has been a strong power of economy for human since olden times (Mahapatra and Mitchell, 1997; Ok, 2005, ilter and Ok, 2007). So the use and supply of wood for the industry have a great importance from past through today (Tezcan et al., 2014). In recent years the use of wood-based panels such as fiberboard, particleboard, oriented strandboard, plywood etc., have been increasing due to the fast growth in building trade in Turkey. The world's largest board producers are China, USA, Germany and Turkey respectively. This charges the industry a great responsibility for the environment because sustainable development is a development that meets the needs of the present without making a concession the ability of future generations to meet their own needs (Tezcan et al., 2014; Yıldırım et al., 2014).

\subsubsection{Researches About Carbon Footprint and Pareto Analysis}

There are many studies about carbon footprint in wood industries throughout the world, but, there is not any research in our country even it is one of the most important developed industry in Turkey. In a study (Garcia et al., 2013) researched the carbon footprint of particleboard produced in Portugal. It was aimed the effect of different methodologies in the particleboard carbon footprint (CF) calculation in using four different CF measurement methods. Those methods are ISOTS14067, the GHG Protocol Product Standard, PAS 2050, and Climate Declaration. In another study (Görener and Toker, 2013), applied in pareto analysis to a firm engaged in forest products industry which is specialized on MDF board (Medium Density Fiber) manufacturing. They aimed to determine and classify failure modes and then make suggestions due to their significance degree by Pareto analysis. They also investigated the occurrence of waste process by using Pareto analysis. In a study researched different uses of wood to see their efficiency by means of carbon and energy impacts to displace fossil energy (Lippke et al., 2012). They suggested when waste wood is consumed as biofuels instead of fossil fuels, the emissions were decreased. In another study (Bergman et al., 2014), researched in the carbon effects of wood products. This study defines to carbon emissions savings when wood products are used in constructing buildings in place of nonwood sources. In another study (Cetin et al., 2014), applied in pareto analysis on the scope and extent of extra work caused by management and workers' issues in the Turkish furniture industry. The aim of this study is to prove and detect factors that decrease of efficiency through issues of management, production processes, supervision of workers and aspects of the products themselves, thereby assisting enterprises obtain essential measures. This study was analyzed with using pareto charts and cause effect diyagram. In another study (Moroşanu et al., 2011), researched on identifying and analyzing defects on oak veneer for four regions. So, the pareto analysis was applied for developing the quality of the studied products.

\section{DATA AND METHODOLOGY}

\subsection{Particleboard Manufacturing Process}

Figure 1: Work Flow with regard to Particle Board Production in X Plant

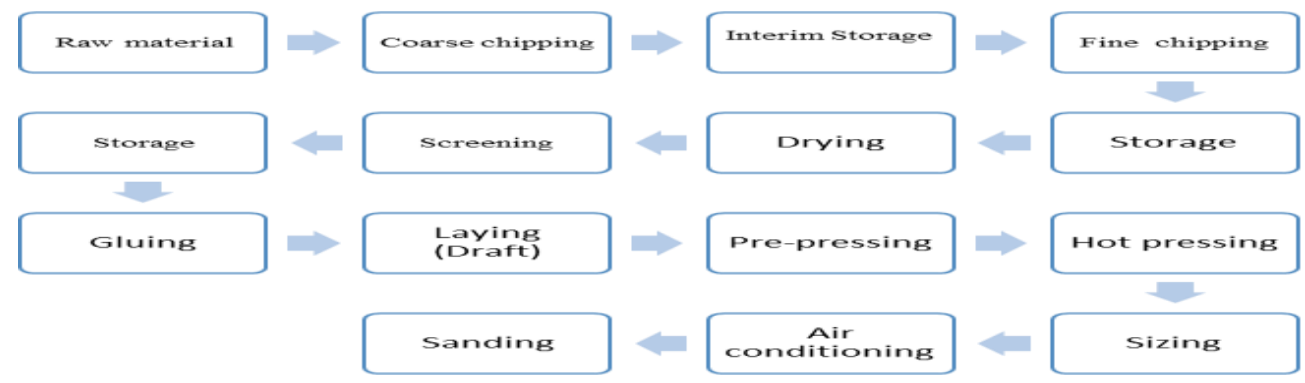

$\mathrm{X}$ is a plant operating in forest products industry and it produces particle board, medium density fiberboard (MDF), and parquet in Marmara region. Work flow in connection with particle board manufacturing is shown in Figure 1. Particle board is described as a panel product manufactured from lignocellulosic materials, in the form of chipped particles in the combination of synthetic resin and suitable binders by the help of heat and pressure. The study is carried out in the particle board plant $(\mathrm{X})$ considering the improvements of all of the energy flow processes comprises of following steps: 
1-Occuring a study plan

2-Calculation of carbon footprints for each of process

3-Applying the Pareto analysis procedures

4-Drawing the Pareto diagram

5-Determine major emission problem(s) according to 80/20 law

6-Give suggestions for major emission problem(s)

\subsection{Methodology}

\subsubsection{Tier Method}

According to IPCC 2007 there are three tiers methods to evaluate emissions. Since the simplicity in application and suitability of the data that we have, Tier 1 method used in this study. Carbon footprints (CF) were calculated for each process with the inputs' emission factors and then Tier 1 method was applied. Process and machinery based data related to energy and fuel consumption used for emission calculations through the formula given below (Pekin, 2006; Atabey, 2013; Turanlı, 2015). Before carbon footprint calculation, it must be known fuel consumption and emission factor. Emission factor can be found in literature (Defra, 2010; Lelyveld and Woods, 2010; Url-1; Url-2). Emission is calculated according to the formula 1 is given in below and CF is calculated according to formula 2 .

Emission $=$ Energy consumption $\times$ Emission factor $\times$ Oxidation factor (Oxidation factor is taken as 1 )

$\mathrm{CF}=$ Emissions $\left(\mathrm{kgCO}_{2}\right) /$ Amounts of annual production $\left(\mathrm{m}^{3}\right)$

\subsubsection{Pareto Analysis}

Vilfredo Pareto was a 19th century Italian economist and analyzed economic problems using mathematics and this method was mentioned as his name and it helps to identify and classify the fault according to percentage significant. He observed that 80 percent of the land in Italy was owned by 20 percent of the population. Then. It is a way of evaluating reasons of problems to provide an effective solution. This method applies due to $80 / 20$ law in general. Cause and effect diagram is useful tool in identifying the major causes. This diagram helps to build a relationship, brainstorming is done with utilizing these quality tools to provide an effective solution (Gitlow et al., 2005). Quality expert J.M. Juran used the rule to quality control and shown that 80 percent of problems stem from 20 percent of possible reasons. Pareto diagrams are the graphical tool applied in Pareto analysis (Cravaner et al.,1993; Leavengood and Reeb, 2002). Pareto analysis is a method which is applied to distinguish reasons from less important ones (Akın, 1996; Ozcan, 2001). Pareto analysis takes the procedures in below:

1. Problems should be identified and then classified

2. Data are classified according to the problem types. Total values which are in different categories and their percentages are defined.

3. A bar chart was drawn. In this bar graph, while the $y$-axis demonstrates the totals and percentages, the $x$-axis shows the classified groups.

4. Pareto diagram is realized to state qualitative totals therefore starting from the upper right-hand corner of the first bar (Akın and Oztürk, 2005) (Figure 2).

Figure 2: Pareto Curve (Url-3)

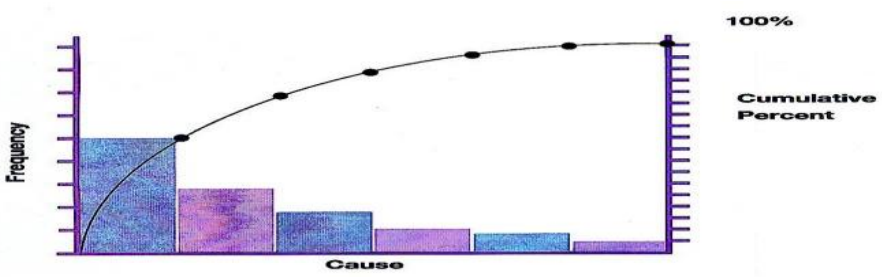

While failure modes are shown on $\mathrm{x}$-axis, the frequency or cost are generally shown on $\mathrm{y}$-axis on Pareto diagram. 


\section{FINDINGS AND DISCUSSIONS}

\subsection{Particle Board Manufacturing Process}

In this plant, natural gas, biomass (dust, wood chips, fiber, broken plate, etc.) and diesel fuel are using as the main inputs for obtaining energy. While natural gas and biomass are using in particle board production process, diesel fuel is consumed by transportation equipment (volvo, escalator and forklift) which are using in the field. Those inputs are primary and direct energy sources for particle board production in process. Since diesel value is very low, it is neglected so the main energy inputs of the process are natural gas and biomass. The total amount of natural gas and biomass as kWh is 232661527 . While the ratio of natural gas consumed is about $75 \%$, biomass ratio is about $25 \%$. Energy flow diagrams were shown in below.

Figure 3: Natural Gas Energy Flow Diagram

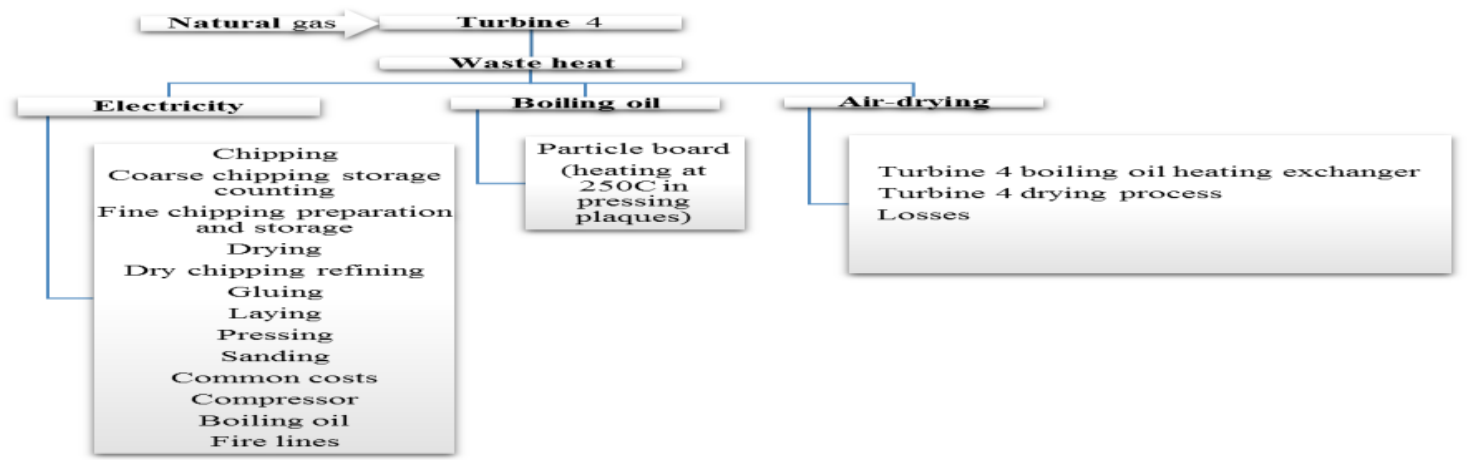

Natural gas is consuming in Turbine 4. As a result of the use of natural gas, waste heat releases. The waste heat is recovering in electricity, boiling oil, and air drying energy sources. Those sources are named as indirectly energy sources or seconder energy sources. So the company produces its own electricity in the plant.

Figure 4: Natural Gas and Biomass Energy Flow Diagram

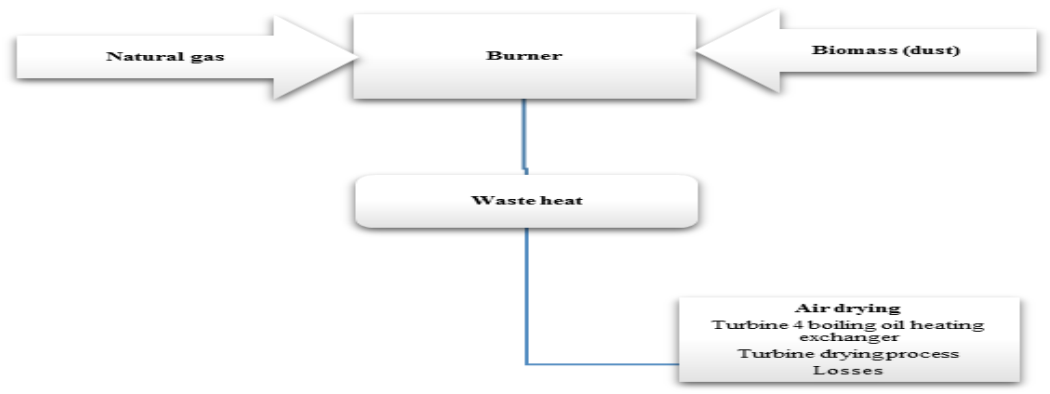

At the same time natural gas and biomass are burned together in the burner to produce energy. As a result of the process, waste heat is also emitting. The waste heat is recovering in air drying energy sources. Those sources are called as indirectly energy sources or seconder energy sources. 
Figure 5: Biomass Energy Flow Diagram

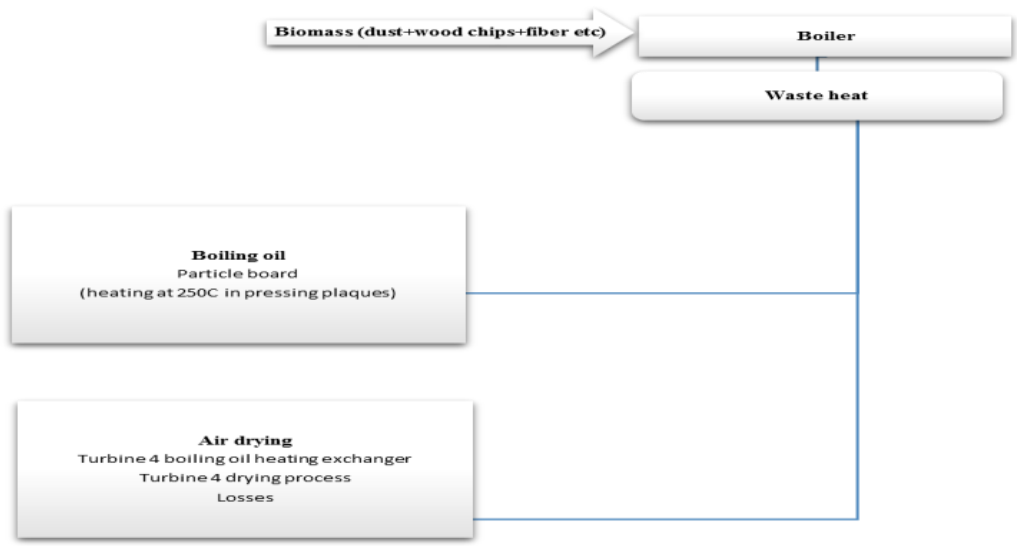

Biomass sources vary from wood dust, wood chips, bark, emery powder, etc. It is generally consisting of

process waste. As a result of the process, waste heat is also emitted. The waste heat is recovered in boiling oil and air drying energy sources. Those sources are called as indirectly energy sources or seconder energy sources.

\subsection{Application of Pareto Analysis}

In this study, CF was calculated for each process sources in particleboard production. Pareto chart was drawn to identify the problems which were revealed by the help of 80/20 law. For this purpose, firstly, CF values of every process' sources were enumerated as shown in Table 1.

Table 1: CF Data According to Source

\begin{tabular}{|l|l|c|}
\hline Serial No & Source & $\begin{array}{c}\text { CF } \\
\text { (kg CO2/m³ particleboard) }\end{array}$ \\
\hline 1 & Turbine 4 & 72.65 \\
\hline 2 & Burner & 5.42 \\
\hline 3 & Chipping & 0.62 \\
\hline 4 & Coarse chipping storage & 0.73 \\
\hline 5 & Fine chipping prepration and storage & 2.89 \\
\hline 6 & Drying & 4.43 \\
\hline 7 & Dry chipping refining & 2.26 \\
\hline 8 & Glueing & 1.06 \\
\hline 9 & Laying & 1,01 \\
\hline 10 & Pressing & 1.85 \\
\hline 11 & Sanding & 0.98 \\
\hline 12 & Common costs & 0.36 \\
\hline 13 & Compressor & 0.71 \\
\hline 14 & Boiling oil & 0.21 \\
\hline 15 & Fire lines & 0.01 \\
\hline 16 & Turbine 4 boiling exchanger & 11.3 \\
\hline 17 & Turbine 4drying process & 39.4 \\
\hline 18 & Losses1 & 9.3 \\
\hline
\end{tabular}




\begin{tabular}{|l|l|c|}
19 & Boiler & 0,93 \\
\hline 20 & Boiling oil boiler & 0.60 \\
\hline 21 & Losses 2 & 0.54 \\
\hline 22 & Transportation equipment & 0.2 \\
\hline
\end{tabular}

Then enumerated values were sorted from high to low and the total amount of CF was found as seen in Table 2.

Table 2: CF datas in sorted from high to low

\begin{tabular}{|c|c|c|}
\hline Serial No & Source & $\begin{array}{c}\mathrm{CF} \\
\left(\mathrm{kg} \mathrm{CO}_{2} / \mathrm{m}^{3} \text { particle board }\right)\end{array}$ \\
\hline 1 & Turbine 4 & 72.65 \\
\hline 17 & Turbine 4 drying process & 39.4 \\
\hline 16 & Turbine 4 boiling exchanger & 11.3 \\
\hline 18 & Losses1 & 9.3 \\
\hline 2 & Burner & 5.42 \\
\hline 6 & Drying & 4.43 \\
\hline 5 & Fine chipping preparation and storage & 2.89 \\
\hline 7 & Dry chipping refining & 2.26 \\
\hline 10 & Pressing & 1.85 \\
\hline 8 & Glueing & 1.06 \\
\hline 9 & Laying & 1.01 \\
\hline 11 & Sanding & 0.98 \\
\hline 19 & Boiler & 0.93 \\
\hline 4 & Coarse chipping storage & 0.73 \\
\hline 13 & Compressor & 0.71 \\
\hline 3 & Chipping & 0.62 \\
\hline 20 & Boiling oil boiler & 0.60 \\
\hline 21 & Losses 2 & 0.54 \\
\hline 12 & Common costs & 0.36 \\
\hline 14 & Boiling oil & 0.21 \\
\hline 22 & Transportati,on equipment & 0.2 \\
\hline 15 & Fire lines & 0.01 \\
\hline \multicolumn{2}{|l|}{ TOTAL } & 157.5 \\
\hline
\end{tabular}

In the third step, as seen in Table 3, percent and cumulative percent were calculated for every sources' of values were took place in Table 2.

Pareto chart was drawn with 3 axes. While y axes in the left side shows CF values, y axes in the right side shows cumulative percent and $x$ axes indicates the sources (Figure 6). 
Table 3: Percent and Cumulative Percent of CF

\begin{tabular}{|c|c|c|c|c|}
\hline Serial No & Source & $\begin{array}{c}\text { CF } \\
\text { (kg CO2/m3 particle board) }\end{array}$ & $\begin{array}{l}\text { Percent } \\
\text { (\%) }\end{array}$ & $\begin{array}{l}\text { Cumulative } \\
\text { percent(\%) }\end{array}$ \\
\hline 1 & Turbine 4 & 72.65 & 46.131 & 46 \\
\hline 17 & Turbine 4 drying process & 39.4 & 25.045 & 71 \\
\hline 16 & Turbine 4 boiling exchanger & 11.3 & 7.155 & 78 \\
\hline 18 & Losses1 & 9.3 & 5.927 & 84 \\
\hline 2 & Burner & 5.42 & 3.441 & 88 \\
\hline 6 & Drying & 4.43 & 2.813 & 91 \\
\hline 5 & Fine chipping preparation and storage & 2.89 & 1.836 & 92 \\
\hline 7 & Dry chipping refining & 2.26 & 1.433 & 94 \\
\hline 10 & Pressing & 1.85 & 1.173 & 95 \\
\hline 8 & Glueing & 1.06 & 0.673 & 96 \\
\hline 9 & Laying & 1.01 & 0.640 & 96 \\
\hline 11 & Sanding & 0.98 & 0.622 & 97 \\
\hline 19 & Boiler & 0.93 & 0.591 & 97 \\
\hline 4 & Coarse chipping storage & 0.73 & 0.464 & 98 \\
\hline 13 & Compressor & 0.71 & 0.448 & 98 \\
\hline 3 & Chipping & 0.62 & 0,391 & 99 \\
\hline 20 & Boiling oil boiler & 0.60 & 0.381 & 99 \\
\hline 21 & Losses 2 & 0.54 & 0.341 & 100 \\
\hline 12 & Common costs & 0.36 & 0.227 & 100 \\
\hline 14 & Boiling oil & 0.21 & 0.135 & 100 \\
\hline 22 & Transportation equipment & 0.2 & 0.127 & 100 \\
\hline 15 & Fire lines & 0.01 & $6 \mathrm{E}-03$ & 100 \\
\hline \multicolumn{2}{|l|}{ TOTAL } & 157.5 & & \\
\hline
\end{tabular}

Figure 6: Application of Pareto Analysis according to Relationships between Source and Carbon Footprint

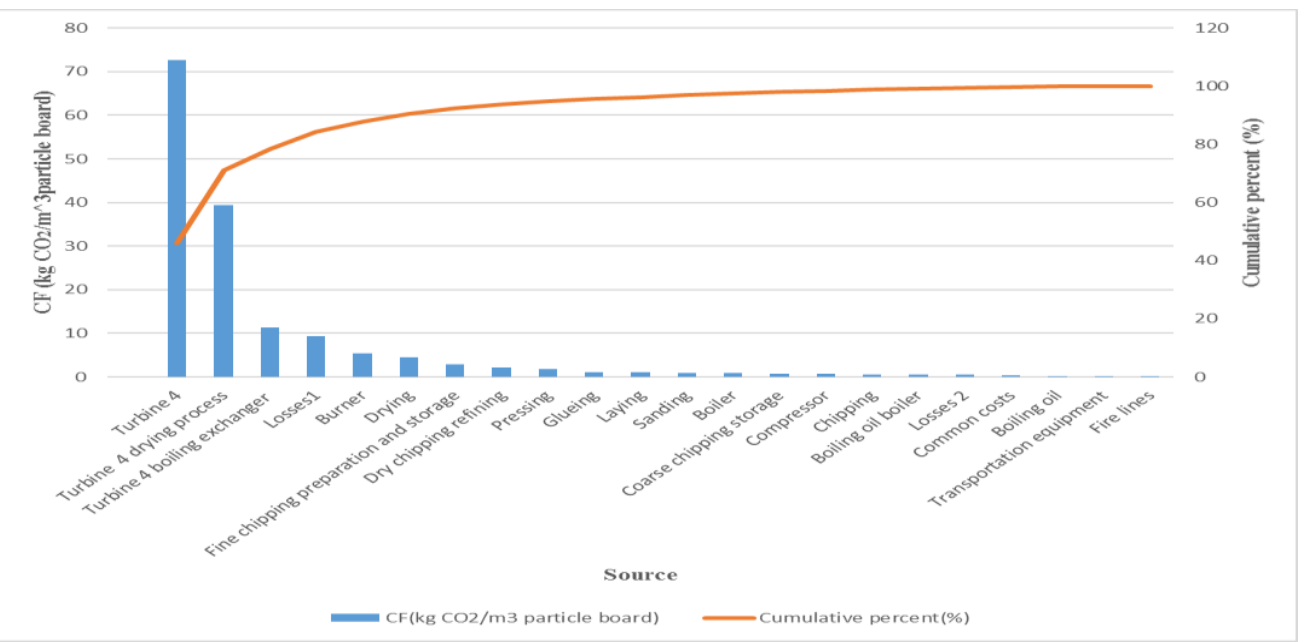

According to the Pareto chart, it was clearly seen that Turbine 4, Turbine 4 drying process and Turbine 4 boiling exchanger are the first three sources constitute $78 \%$ of the total sources (Figure 6).

According to the $80 / 20$ law and the results that we obtained in the Pareto chart, the problems are originated from Turbine 4 , Turbine 4 drying process and Turbine 4 boiling exchanger. While these causes of three sources are $22 \%$ of 22 sources, the first three sources occur $78 \%$ of total sources. 


\section{CONCLUSION}

In this study, it was demonstrated that the total amount of 3 sources which take place in sequences of 22 sources in the process correspond to $78 \%$ of total amount of the sources with Pareto chart by the help of $80 / 20$ law. So it can be suggested some improvements primarily for these 3 sources which are called Turbine 4, Turbine 4 drying process and Turbine 4 boiling exchanger. It can be offered that these sources may consume biomass energy instead of natural gas as an energy source. Besides, other renewables such as sun panels can be used as an energy source. Some best available techniques (BAT) can also be recommended. These techniques are explained below (Federal Environment Agency, 2011; BAT, 2014):

-Staff must be trained to improve environmental awareness periodically

-Environmental management system must be applied for control of procedures and carry out responsibilities by personnel

- Equipments' maintenance must be provided regularly

\section{REFERENCES}

Akın, B.1996, “ISO 9000 Uygulamasında İşletmelerde İstatistik Proses Kontrol Teknikleri”, Istanbul: Bilim Teknik Yayınevi, pp 49-50.

Akın, B., Öztürk, E. 2005, “Istatistiksel Proses Kontrol Tekniklerinin Bilgisayar Ortamında Uygulanması”, VII.Ulusal Ekonometri ve İstatistik Sempozyumu Bildiriler CD, Istanbul, pp 1-15.

Atabey, T. 2013, “Karbon Ayak İzinin Hesaplanması: Diyarbakır Örneği”, Fırat Üniversitesi Yüksek Lisans Tezi, Elazığ.

Bergman, R., Taylor, A., Skog, K.E., Puettmann, M.E. 2014, “The Carbon Impacts of Wood Products”, Forests Products Journal Vol 64 No. 7, 14 October.

Best Available Techniques (BAT) 2014, "Reference Document for the Production of Wood-based Panels"

Calculating our carbon footprint convert kWh electricity to kg CO2; draft, Url-2 http://www.leicsgov.ukcalculating_our_carbon_footprint.pdf Carbon Trust, 2007, "Carbon Footprint Measurement Methodolgy" (Draft) www.carbontrust.co.uk

Cetin, T., Colak, M., Yılmaz, S., Yılmaz, T., Korkmaz, Y. 2014, "The Scope and Extent of Extra Work Caused by Management and Workers' Issues In The Turkish Furniture Industry", Journal of Asian Scientific Research 4 (12): pp 729-740, Muğla.

Cravener, T.L., Roush, W.B., Jordan, H., 1993, "Pareto Assessment of Quality Control in Poultry Processing Plants", Applied Poultry Science, 2: pp 297-302.

DEFRA,2010, biomass emission factors.

Federal Environment Agency, Brigitte Zletlow. lichtl Ethıcs\& Brands, May 2011, "Environmental Standards In The Textile And Shoe Sector-A Guideline On The Basis Of The Brefs-Best Available Techniques Reference Documents Of The EU-Umwelt Bundes Amt"

Garcia, R., Freire, F., 2013, Carbon footprint of particleboard: a comparison between ISO/TS 14067, GHG Protocol, PAS 2050 and Climate Declaration.

Gitlow, H.S., Openheim, A.J., Oppenheim, R., Levine, D.M. 2005, “Quality Management”, Third Edition, McGrawHill, USA, pp 366-367.

Görener, A., Toker, K. 2013, "Quality Improvement in Manufacturing Process to Defective Products using Pareto Analysis and FMEA", Beykent University Journal of Social Sciences-BUJSS Vol.6 No.2, ISSN:1307-5063, Istanbul.

Grubb and Ellis, 2007, "Meeting the Carbon Challenge: The Role of Commercial Real Estate Owners", Users \& Managers, Chicago.

Guidelines for Measuring and Managing CO2 emission from Freight Transport Operations, March 2011(draft) Url-1 http://www.cefic.org/Documents/IndustrySupport/Transport-and-Logistics/Best\%20Practice\%20Guidelines\&20-\%20General\%20 Guidelines/CeficECTA\%20Guidelines\%20for\%20measuring\%20and\%20managing\%20CO2\%20emissions\%20from\%20transport\%20operation s\%20Final\%20,30.03.2011.pdf

Hammond, G. 2007, "Time to give due weight to the 'carbon footprint' issue". Nature 445(7125): 256. http://dx.doi.org/10.1038/445256b.

IPCC Climate Change, 2007: "Synthesis Report.Contribution of Working Groups I, II, and III to the Fourth Assessment Report of the Intergovermental Panel on Climate Change (IPCC)", Geneva

IPCC, 2006, "Guidelines for National Greenhouse Gas Inventories, Chapter 10: Emissions from livestock and manure management", Retrieved from http://www.ipcc nggip.iges.or.jp/public/2006gl/pdf/4_10_Ch10_Livestock.pdf.

IPCC 2007 Revised 2007" IPCC Guideliness for National Greenhouse Gas Inventories: Revence Manual Intergovermental Panel on Climate Change", Cambridge University Press, Cambridge 
Ilter, E.; Ok, K. 2007, “Ormancılık ve Orman Endüstrisinde Pazarlama IIlkeleri ve Yönetimi” (Forestry and Forest Industry Marketing Principles and Management), Ankara, Turkey.

Leavengood, S. and Reeb, J.,2002, "Part 3: Pareto Analysis and Check Sheets, Performance excellence in the wood products industry Statistical Process Control", EM 8771, January 2002.

Lelyveld, T., Woods, P., AECOM 2010, “Carbon emission factors for fuels -Methodology and values for 2013-2016”, 6 October 2010.

Lippke, B., Gustafson, R., Venditti, R., Steele, P., Volk, T.A., Oneil, E., Johnson, L.,Puettmann,M.E., Skog,K. 2012, “Comparing Life-Cycle Carbon and Energy Impacts for Biofuel, Wood Product, and Forest Management Alternatives", Forest Products Journal Volt.62 (4): pp 247257.

Mahapatra, A.; Mitchell, C.P. 1997, "Sustainable development of non-timber forest products: implication for forest Management in India", Forest Ecology and Management 94: pp 15-29.

Managers net, Pareto analysis( the 80:20 rule),(draft) Url-3 http://www.managers-net.com/paretoanalysis.html

Morşanu, C., Dumitraşcu, A., E., Ciobanu, V. 2011, "The Influence of Oak Raw Timber Defects on Decorative Veneer Cutting" , Bulletin of the Transilvania University of Braşov Series II Foresty Wood Industry Agricultural Food Engineering Vol 4(53) No. 2

Muthu, S.S. 2014, "Assessment of Carbon Footprint in Different Industrial Sectors", Volume 1, Springer, Environemntal Issues in Logistics and Manufacturing, ISBN 978-981-4560-41-2, London.

Ok, K. 2005, "Idea Marketing in Forestry: Some Implications from the Turkish Forestry Experience". Forest Policy and Economics 7(4): pp 493-500.

Özcan, S. 2001, "istatistiksel Proses Kontrol Tekniklerinden Pareto Analizi ve Çimento Sanayiinde Bir Uygulama” , C.Ü. İktisadi ve İdari Bilimler Fakültesi Dergisi, 2 (2): pp 151-174.

Pekin, M., 2006, “Ulaştırma Sektöründen Kaynaklanan Sera Gazı Emisyonları Yüksek Lisans Tezi”, Haziran 2006, iTÜ

POST, 2006, "Carbon footprint of electricity generation". POSTnote 268, October 2006, Parliamentary Office of Science and Technology, London, UK. http://www.parliament.uk/documents/upload/postp n268.pdf.

Turanlı, A. 2015, "Estimation of carbon footprint: A case study for Middle East Technical University Mastar Thesis" , May 2015, Middle East Technical University.

UN, 1998, "Kyoto protocol to the United Nations framework convention on climate change", United Nations.

Wackernagel, M., and Rees, W. 1996, "Urban ecological footprints Why cities cannot be sustainable-And why they are a key to sustainability", Environmental Impact Assessment Review Volume 16, Issues 4-6, July-November 1996, pp223-248.

What is a Carbon Footprint? Report presented to The Swedish Forest Industries Federation and Timcon by The Edinburg Centre for Carbon Management ECCM-EM-483-2007, February 2008 (Draft) http://www.timcon.orgCarbonCalculatorCarbon\%20Footprint.pdf

Wiedmann, T., and Minx, J. 2007," A Definition of 'Carbon Footprint' “, ISA UK Research Report 07-01, June 2007.

Yildirim, T., Candan, Z. and Korkut.S. 2014, "Wood-Based Panels Industry In Turkey: Future Raw Material Challenges And Suggestions. Maderas. Ciencia y tecnología 16 (2): pp 175-186. 